\title{
Analisis Perbandingan Metode LVQ Dan Backpropagation dalam Penentuan Keaslian Uang Kertas Rupiah Berbasis Parameter HSV
}

\author{
http://dx.doi.org/10.28932/jutisi.v5i1.916
}

\author{
I Gusti Ayu Agung Diatri Indradewi ${ }^{\# 1}$, I Ketut Widhi Adnyana ${ }^{* 2}$ \\ ${ }^{\#}$ Teknik Informatika, STMIK STIKOM INDONESIAI \\ Jl.Tukad Pakerisan No 97, Panjer Denpasar \\ ${ }^{1}$ diatri.indradewiestiki-indonesia.ac.id \\ ${ }^{*}$ Teknik Informatika, STMIK STIKOM INDONESIA ${ }^{2}$ \\ Jl.Tukad Pakerisan No 97, Panjer Denpasar \\ ${ }^{2}$ ketut.widhi@stiki-indonesia.ac.id
}

\begin{abstract}
The high demand of the community for money that causes crime is the circulation of fake paper money. Counterfeit money if shared has the same physical as the original money issued by Bank Indonesia. To avoid the public accidentally transacting using counterfeit money, the government has actually socialized the 3D method (Seen, Diraba, and Diterawang). However, along with technological developments, the technique of making counterfeit money will also require the development of alternative techniques that can be used to help save fake money. Determining the authenticity of Rupiah banknotes can be done using pattern classification methods, one of which can be accommodated by artificial neural networks. LVQ neural network (Learning Vector Quantization) and Backpropagation are two types of artificial neural networks that do supervised learning. Extraction of features that show the authenticity of banknotes can be done using the HSV color space. This color space consists of components $H$ (Hue), $S$ (Saturation), and $V$ (Value). This is the background of the topic chosen for analysis choosing the LVQ and Backpropagation methods in determining the authenticity of Rupiah banknotes based on HSV parameters. Evaluation analysis taken from the level assessment The evaluation results using the composition of the test data consisting of $\mathbf{1 0}$ original money images and 8 original money images obtained results both LVQ and Backpropagation networks were able to classify real and fake money images with $100 \%$ acquisition rates. However, when viewed from the MSE value, the LVQ network has a better performance with the supporting MSE value being 0. The test results from the preparation time, the Backpropagation network requires a shorter time compared to the LVQ network.
\end{abstract}

Keywords - LVQ, Backpropagation, Indonesian Rupiah Banknotes, MSE, HSV

\section{Pendahuluan}

Menurut KBBI, uang adalah alat tukar atau standar pengukur nilai (kesatuan hitungan) yang sah, dikeluarkan oleh pemerintah suatu negara berupa kertas, emas, perak, atau logam lain yang dicetak dengan bentuk dan gambar tertentu. Sebagai alat tukar yang berlaku umum di masyarakat, uang menjadi aspek yang tidak dapat terpisahkan dari berbagai bidang kehidupan. Hampir segala jenis kebutuhan mulai dari primer hingga tersier hanya bisa terpenuhi ketika sejumlah uang telah dimiliki.

Teknologi pengenalan keaslian uang kertas pada dasarnya adalah mencari dan mengekstraksi tanda keaslian yang terlihat maupun tersembunyi pada uang kertas agar proses klasifikasi berlangsung lebih efisien [1]-[3]. Secara umum, ciri-ciri keaslian uang kertas Rupiah cukup mudah dikenali oleh masyarakat berupa unsur pengaman yang tertanam pada bahan uang dan teknik cetak yang digunakan. Unsur pengaman yang tertanam pada bahan uang kertas terdiri dari tanda air (watermark) dan electrotype, dan benang pengaman (security thread). Unsur pengaman yang dihasilkan melalui teknik cetak terdiri dari cetak dalam/intaglio, gambar saling isi (rectoverso), tinta berubah warna (optically variable ink), tulisan mikro (microtext), cetakan tidak kasat mata (invisible ink), dan gambar tersembunyi (latent image) [4],[5].

Ekstraksi fitur-fitur yang menunjukkan keaslian dari uang kertas dapat dilakukan dengan memanfaatkan metodemetode yang terdapat pada Pengolahan Citra Digital. Salah satu metode yang dapat digunakan adalah melalui pemisahan komponen warna pada citra uang kertas. Pemisahan komponen warna dilakukan pada ruang warna HSV. Ruang warna HSV merupakan ruang warna yang terdiri dari komponen H (Hue), S (Saturation), dan V (Value). Komponen $\mathrm{H}$ menyatakan jenis-jenis warna seperti merah, kuning, hijau, biru, dan magenta. Komponen S menyatakan seberapa banyak komposisi cahaya putih bercampur dengan komponen $\mathrm{H}$. Komponen $\mathrm{V}$ menyatakan kecerahan warna [6],[7]. Untuk melakukan pemisahan 
komponen warna pada ruang warna HSV, citra uang kertas yang berada pada ruang warna RGB dikonversi ke ruang warna HSV. Salah satu keunggulan ruang warna HSV adalah memiliki kemampuan untuk memisahkan komponen kromatik dan akromatik pada suatu citra [8].

Penentuan keaslian uang kertas Rupiah dapat dilakukan dengan menggunakan metode pengklasifikasian pola yang salah satunya dapat diakomodasi oleh jaringan syaraf tiruan. Jaringan syaraf tiruan merupakan model jaringan yang meniru prinsip kerja dari neuron otak manusia (neuron biologis). Jaringan syaraf tiruan memiliki beberapa kemampuan seperti yang dimiliki oleh otak manusia, yaitu kemampuan untuk belajar dari pengalaman, kemampuan melakukan perumpamaan (generalization) terhadap masukan baru dari pengalaman yang dimilikinya, dan kemampuan memisahkan (abstraction) karakteristik penting dari masukan yang mengandung data yang tidak penting. Jaringan syaraf LVQ (Learning Vector Quantization) dan Backpropagation merupakan dua jenis jaringan syaraf tiruan yang melakukan pembelajaran secara terawasi (supervised learning).

LVQ adalah jaringan syaraf yang bertipe arsitektur Single Layer Feedforward, yakni sinyal masukan akan dipropagate menuju lapisan keluaran. Menurut Difla, LVQ mengklasifikasikan masukan secara berkelompok ke dalam kelas yang sudah didefinisikan melalui jaringan yang telah dilatih. Metode ini melakukan pembelajaran pada lapisan kompetitif yang terawasi. Suatu lapisan kompetitif akan secara otomatis belajar untuk mengklasifikasikan vektorvektor masukan. Kelas-kelas yang didapatkan merupakan hasil dari lapisan kompetitif yang hanya bergantung pada jarak antara vektor-vektor masukan [9]. Jika Single Layer Feedforward hanya memiliki satu lapisan yang akan mempropagate sinyal masukan menuju lapisan keluaran, maka Multilayer Perceptron dapat memiliki satu atau lebih lapisan yang tersembunyi dari lapisan masukan dan keluaran. Salah satu metode yang populer digunakan untuk melatih Multilayer Perceptron adalah algoritma Backpropagation. Algoritma tersebut terdiri dari dua fase, yakni forward phase dan backward phase [10]. LVQ maupun Backpropagation dapat digunakan untuk mengklasifikasikan suatu pola [11]. Hal tersebut melatarbelakangi dipilihnya topik mengenai analisis perbandingan metode LVQ dan Backprpagation dalam penentuan keaslian uang kertas Rupiah berbasis parameter HSV. Analisis perbandingan akan diukur dari sisi tingkat akurasi, kedekatan hasil klasifikasi dengan hasil sesungguhnya, dan waktu pemrosesan klasifikasi. penelitian ini bertujuan untuk mengetahui hasil perbandingan metode LVQ dan Backpropagation dalam penentuan keaslian uang kertas Rupiah jika diukur dari waktu pemrosesan klasifikasi, serta manfaat yang didapat adalah penelitian dapat menjadi refrensi tambahan mengenai metode-metode yang dapat digunakan untuk menentukan keaslian uang rupiah, selain itu penelitian ini diharapkan dapat menjadi salah satu bahan studi awal mengenai pengembangan aplikasi pendeteksi uang palsu dengan sumber cahaya ultraviolet.

\section{Metodologi Penelitian}

Secara garis besar, penelitian ini akan menghasilkan prototype sistem yang dapat digunakan untuk menyimulasikan perbandingan metode LVQ dan Backpropagation dalam penentuan keaslian uang kertas Rupiah. Alur penelitian yang digunakan ditunjukkan pada Gambar 1. Analisis masalah diawali dengan pengumpulan data dengan metode dokumentasi berupa dokumen statistik temuan uang Rupiah palsu yang dipublikasikan oleh Bank Indonesia. Metode dokumentasi dilakukan untuk pencarian data awal mengenai jumlah peredaran uang Rupiah palsu di Indonesia. Data awal dianalisis untuk menentukan permasalahan.

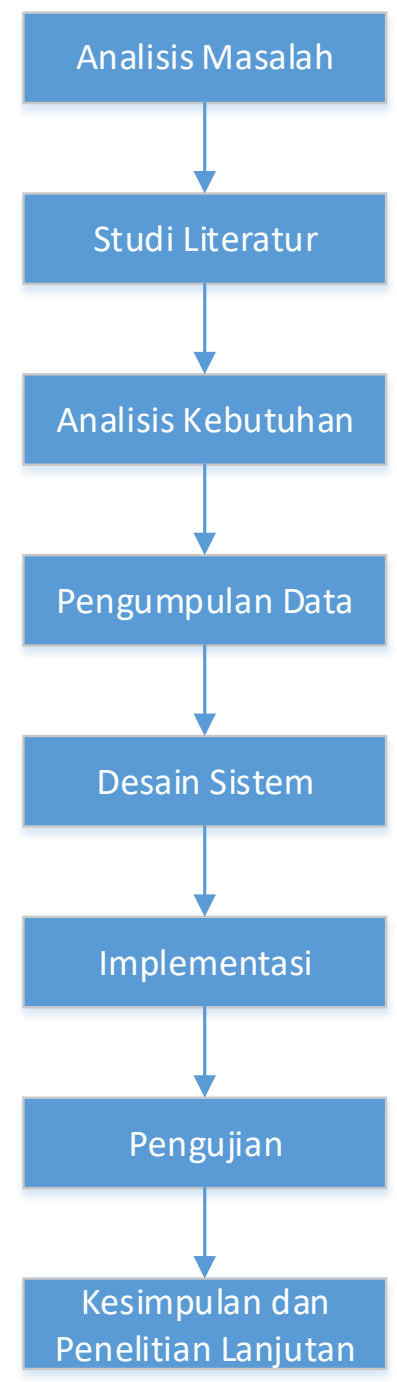

Gambar 1. Alur Penelitian 
Studi literatur dilakukan untuk mencari referensireferensi baik berupa teori pendukung maupun jurnal-jurnal yang memuat berbagai jenis penelitian terkait dengan permasalahan yang telah didefinisikan. Berdasarkan studi literatur, kebutuhan-kebutuhan yang diperlukan dalam sistem dianalisis. Tahap pengumpulan data dilakukan untuk memperoleh data yang akan dijadikan sebagai data sampel pelatihan dan pengujian sistem. Data yang dikumpulkan berupa uang kertas Rupiah asli dan palsu. Desain sistem disesuaikan dengan format data yang dihasilkan dari pengumpulan data. Prototype sistem yang dihasilkan dari tahap implementasi selanjutnya diuji untuk mengetahui tingkat akurasi sistem dalam menentukan keaslian uang kertas Rupiah. Tahap akhir dari sistematika penelitian ini adalah menentukan kesimpulan dan arah penelitian selanjutnya berdasarkan hasil pengujian sistem

\section{ANALISIS DAN PERANCANGAN}

Pada bagian ini akan membahas tentang analisis yang sudah dilakukan serta perancangan dari sistem yang akan dibangun

\section{A. Data Penelitian}

Data yang digunakan dalam penelitian ini berupa uang kertas dengan nominal Rp 100.000,00. Uang kertas tersebut selanjutnya didigitasi dengan menggunakan kamera digital dengan pencahayaan ultraviolet. Format citra digital yang digunakan adalah .bmp. Data uang kertas asli dan palsu yang digunakan pada penelitian ini ditunjukkan pada Tabel I. Uang kertas yang digunakan terdiri dari uang asli dan palsu. Uang kertas asli berjumlah 10 lembar, sedangkan uang kertas palsu berjumlah 8 lembar. Pengambilan gambar dilakukan terhadap masing-masing uang kertas tersebut baik asli maupun palsu sebanyak 10 kali dengan arah pencahayaan yang berbeda. Total data yang digunakan dalam penelitian ini adalah 100 data uang asli dan 80 data uang palsu. Ukuran citra yang digunakan adalah $425 \times 181$ pixel.

TABEL I

DAta UANG KeRTAS ASLi DAN PALSU

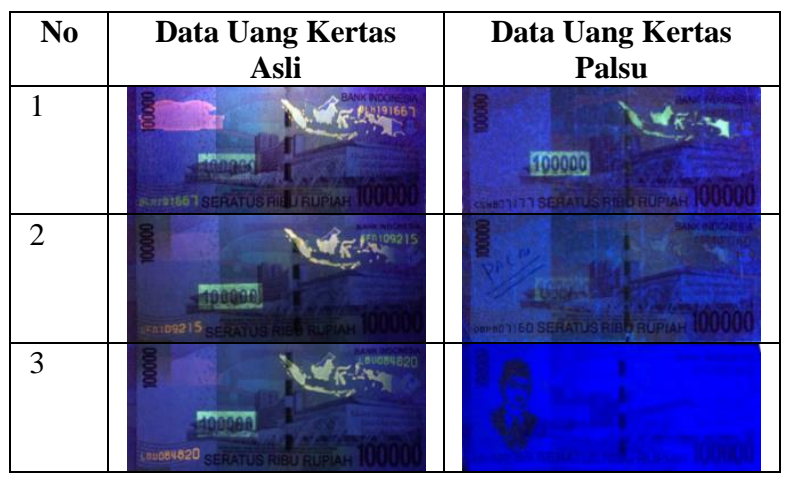

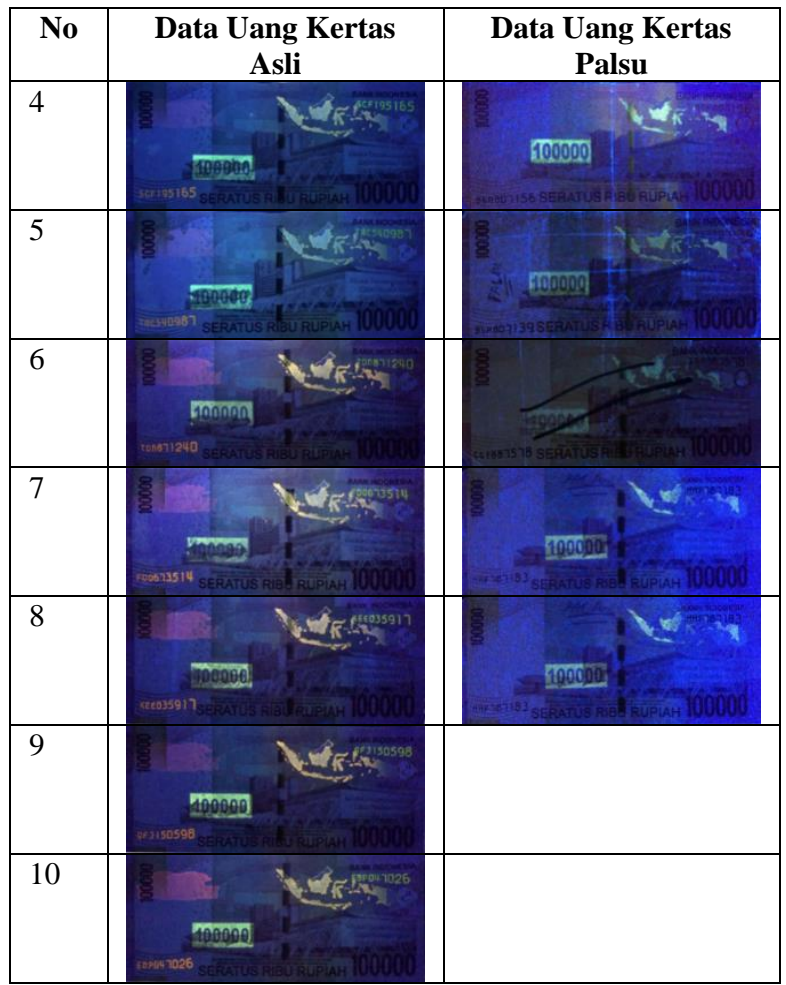

\section{B. Analisis Sistem}

Berdasarkan publikasi pada laman Bank Indonesia (http://www.bi.go.id) mengenai statistik sistem pembayaran, diperoleh gambaran bahwa temuan uang Rupiah palsu mengalami fluktuasi yang trennya cenderung menaik. Kenaikan tertinggi penemuan uang Rupiah palsu terjadi dari tahun 2014 ke 2015. Meskipun dari tahun 2015 ke 2016 terjadi penurunan temuan uang Rupiah palsu, tetap saja peredaran uang palsu merupakan permasalahan yang sangat sulit dihentikan. Selama uang menjadi alat tukar yang berlaku secara luas, selama itu pula uang palsu akan tetap beredar. Salah satu cara yang umum digunakan untuk mendeteksi uang palsu adalah dengan menyinari uang tersebut dengan lampu ultraviolet. Cahaya dari lampu tersebut akan memunculkan perubahan warna tinta pada beberapa bagian dari uang kertas. Namun, seiring dengan teknologi yang berkembang semakin pesat, teknik pembuatan uang palsu tentunya juga akan mengalami perkembangan sehingga diperlukan metode pelengkap yang dapat digunakan untuk membantu mengidentifikasi uang palsu secara otomatis.

Sistem yang dibangun akan menyimulasikan penggunaan metode jaringan syaraf tiruan LVQ dan Backpropagation dalam mengklasifikasikan pola dari fitur-fitur yang telah diekstrak dari citra uang kertas ke dalam kelas-kelas yang bersesuaian. Algoritma pelatihan yang digunakan untuk masing-masing jaringan syaraf tiruan berbeda, karena kedua jaringan tersebut merupakan dua jaringan dengan model yang berbeda. Jaringan LVQ merupakan single layer feedforward dan pembelajarannya berlangsung di lapisan 
kompetitif, sedangkan jaringan Backpropagation merupakan multilayer perceptron yang dapat memiliki satu atau lebih lapisan tersembunyi. Citra uang kertas yang digunakan hanya nominal $\mathrm{Rp} 100.000,00$, karena nominal ini merupakan nominal uang kertas tertinggi sehingga lebih menarik untuk dipalsukan. Berdasarkan observasi awal yang dilakukan di Koperasi STMIK STIKOM Indonesia dan Yayasan Dwijendra Denpasar, juga ditemukan bahwa nominal uang kertas yang dipalsukan hampir seluruhnya adalah nominal Rp 100.000,00. Data citra uang kertas yang telah terkumpul selanjutnya didigitasi dengan menggunakan kamera digital dengan sumber pencahayaan dari lampu ultraviolet. Penggunaan lampu ultraviolet dilakukan untuk memunculkan perubahan warna pada beberapa bagian dari uang kertas. Citra uang kertas yang telah didigitasi selanjutnya di-crop untuk mendapatkan bagian citra yang dominan mengalami perubahan warna tinta saat terkena cahaya ultraviolet. Bagian citra yang telah di-crop selanjutnya dikonversi ke ruang warna HSV. Hasil konversi nantinya berupa vektor yang terdiri dari komponen hue, saturation, dan value. Vektor yang dihasilkan akan menjadi masukan pada jaringan LVQ dan Backpropagation untuk selanjutnya dilakukan pengklasifikasian ke kelas asli atau palsu. Kinerja sistem dalam melakukan klasifikasi diukur dengan MSE dan tingkat akurasi. Selain kedua hal tersebut, sistem juga diuji dari sisi waktu yang dibutuhkan ketika jaringan LVQ dan Backpropagation melakukan klasifikasi.

\section{Rancangan Jaringan Syaraf Tiruan LVQ}

Pada penelitian ini jaringan syaraf tiruan LVQ akan dibangun dengan menggunakan fungsi MATLAB, yakni I vqnet. Seperti yang ditunjukkan pada Gambar 2, jaringan yang dibentuk akan memiliki sebuah input, dua lapisan, dan sebuah output. Dua lapisan yang dimaksud adalah lapisan kompetitif dan lapisan linier. Pada bagian input, nilai 40.320 diperoleh dari jumlah elemen pada vektor hasil konversi dari ruang warna RGB ke HSV. Pada lapisan pertama (lapisan kompetitif) terdiri dari 10 neuron, sedangkan lapisan kedua (lapisan linier) hanya terdiri dari dua kelas saja. Pada bagian output memiliki jumlah neuron yang sama, yaitu 2 yang akan mewakili kelas asli (1) dan kelas palsu (2).

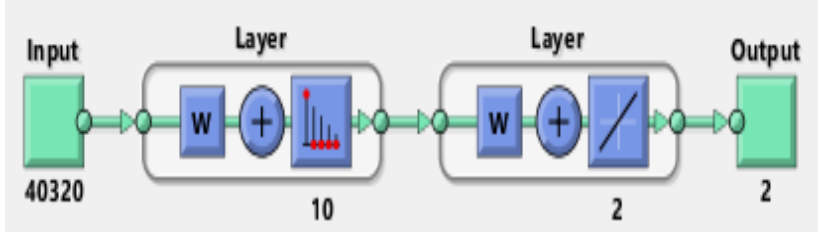

Gambar 2. Jaringan Syaraf Tiruan LVQ

\section{Rancangan Jaringan Syaraf Tiruan Backpropragation}

Pada penelitian ini jaringan syaraf tiruan Backpropagation akan dibangun dengan menggunakan fungsi MATLAB, yakni newff. Seperti yang ditunjukkan pada Gambar 3, jaringan yang dibentuk akan memiliki sebuah input, dua lapisan, dan sebuah output. Dua lapisan yang dimaksud adalah lapisan tersembunyi. Pada bagian input, nilai 40.320 diperoleh dari jumlah elemen pada vektor hasil konversi dari ruang warna RGB ke HSV. Pada lapisan pertama (lapisan tersembunyi) terdiri dari 2 neuron, sedangkan lapisan kedua (lapisan linier) hanya terdiri dari dua kelas saja. Pada bagian output memiliki jumlah neuron yang sama, yaitu 2 yang akan mewakili kelas asli (1) dan kelas palsu (2).

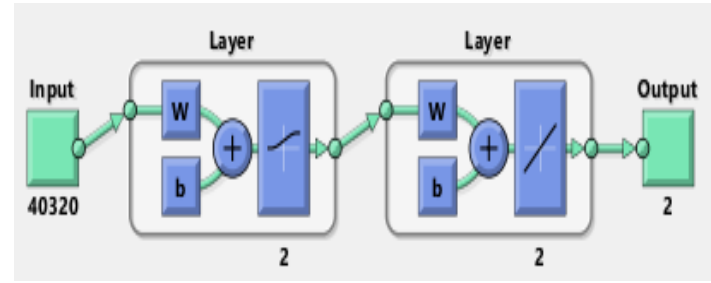

Gambar 3. Jaringan Syaraf Tiruan Backpropagation

\section{E. Implementasi Jaringan $L V Q$}

Implementasi jaringan LVQ dilakukan dengan menggunakan MATLAB seperti yang ditampilkan pada Gambar 4. Fungsi MATLAB yang dijalankan adalah lvqnet yang dijalankan dengan memberikan dua argumen, yakni jumlah lapisan kompetitif dan laju pembelajaran. Algoritma pelatihan yang digunakan pada jaringan LVQ adalah Random Weight/Bias Rule. Kelebihan penggunaan algoritma tersebut dalam pelatihan, yakni, jika neuron tidak pernah memenangkan kompetisi karena bobotnya jauh dari salah satu vektor input, maka nilai biasnya akan menjadi cukup besar sehingga neuron tersebut bisa memenangkan kompetisi. 


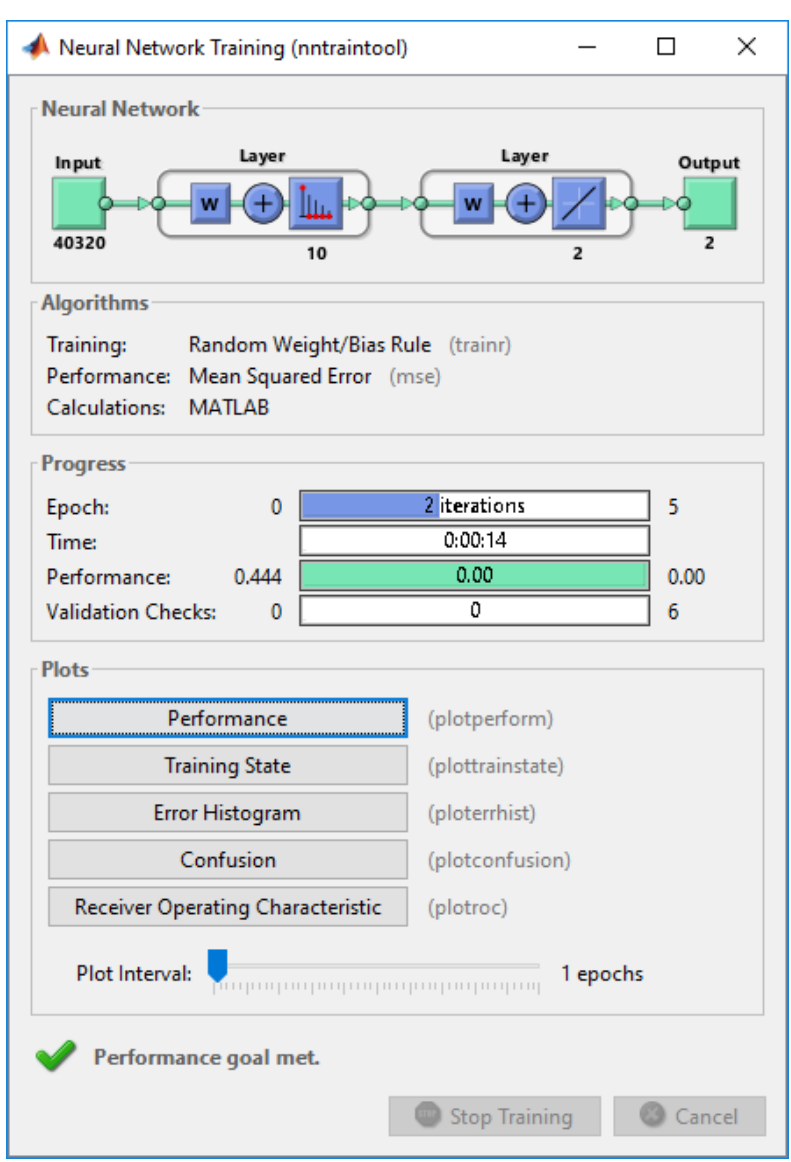

Gambar 4. Implementasi Jaringan LVQ

Hasil konversi nilai RGB citra uang kertas ke dalam ruang warna HSV dijadikan sebagai vektor masukan pada jaringan LVQ yang dibentuk. Jumlah elemen pada vektor masukan adalah 40.320. Jaringan LVQ yang dibentuk terdiri dari lapisan masukan (input) dengan jumlah 40.320 yang sesuai dengan jumlah elemen pada vektor masukan, lapisan kompetitif (competitive layer) dengan jumlah 10 neuron, lapisan linier (linear layer) dengan jumlah 2 neuron, dan lapisan keluaran (output layer) dengan jumlah 2 neuron. Keluaran dari jaringan LVQ direpresentasikan ke dalam dua kelas, yakni kelas 1 untuk kategori asli dan kelas 2 untuk kategori palsu. Jumlah maksimum epoch yang digunakan adalah 5 .

Jaringan LVQ yang dibentuk dilatih berdasarkan laju pembelajaran dan jumlah maksimum epoch yang digunakan dalam menentukan kelas yang sesuai untuk data latih. Data latih yang digunakan terdiri dari 10 uang kertas asli dan 8 uang kertas palsu. Setiap data, baik uang asli maupun palsu dilakukan pengambilan citra sebanyak 9 kali, sehingga komposisi data latih yang digunakan terdiri dari 90 citra uang asli dan 72 citra uang palsu. Jaringan LVQ yang telah dilatih selanjutnya diuji dalam melakukan klasifikasi untuk menentukan citra data uji yang digunakan adalah uang asli atau uang palsu. Komposisi data uji yang digunakan terdiri dari 10 citra uang asli dan 8 citra uang palsu
1) Pelatihan dan Pengujian dengan Laju Pembelajaran $\alpha(0)=0,1$ dan Epoch $=1$

Gambar 5 menunjukkan kinerja terbaik jaringan LVQ dalam menentukan kelas dari citra uang kertas adalah pada saat jumlah maksimum epoch $=1$ tercapai. Nilai MSE jaringan LVQ pada kinerja terbaiknya adalah ketika mencapai nilai 0,055556. Nilai tersebut menunjukkan bahwa laju klasifikasi ke kelas yang tidak bersesuaian (missclasification rate) paling sedikit terjadi pada saat jaringan mencapai epoch $=1$, yakni sebesar $5.5556 \%$.

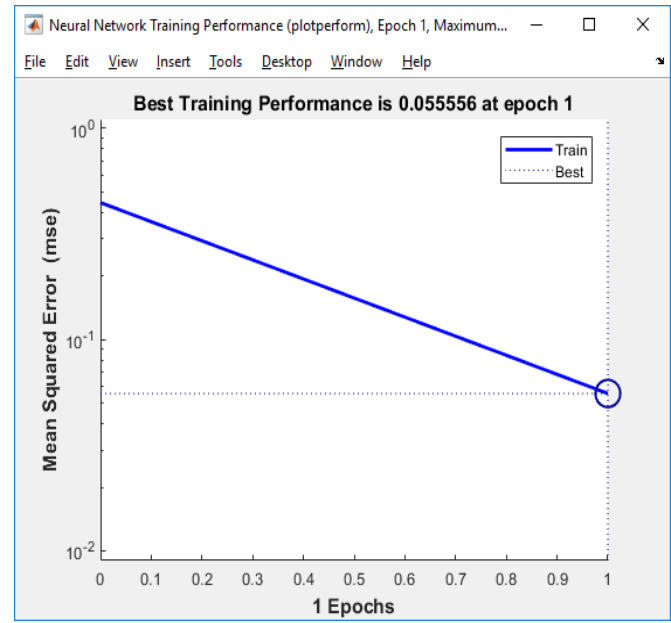

Gambar 5. Grafik Performance Jaringan LVQ pada Laju Pembelajaran $\alpha(0)=0,1$ dan Epoch $=1$

Waktu yang dibutuhkan untuk melakukan pelatihan dan pengujian dengan laju pembelajaran $\alpha(0)=1$ dan jumlah maksimum epoch $=1$ adalah 10 detik. Tingkat akurasi jaringan dalam melakukan klasifikasi adalah 94,4\%. Hasil pengujian ditampilkan pada Tabel II.

TABEL III

Hasil Pengujian PADA Laju PEMBELAJARAN $\alpha(0)=0,1$ DAN EPOCH $=1$

\begin{tabular}{|l|l|l|l|l|l|}
\hline No & $\begin{array}{l}\text { Targ } \\
\text { et }\end{array}$ & Klasifikasi & No & Target & $\begin{array}{c}\text { Klasifi } \\
\text { kasi }\end{array}$ \\
\hline $\mathbf{1}$ & $\begin{array}{l}\text { Asli } \\
(1)\end{array}$ & Asli (1) & $\mathbf{1 0}$ & Asli (1) & Asli (1) \\
\hline $\mathbf{2}$ & $\begin{array}{l}\text { Palsu } \\
(2)\end{array}$ & Palsu (2) & $\mathbf{1 1}$ & Asli (1) & Asli (1) \\
\hline $\mathbf{3}$ & $\begin{array}{l}\text { Asli } \\
(1)\end{array}$ & Asli (1) & $\mathbf{1 2}$ & Palsu (2) & $\begin{array}{l}\text { Palsu } \\
(2)\end{array}$ \\
\hline $\mathbf{4}$ & $\begin{array}{l}\text { Palsu } \\
(2)\end{array}$ & Palsu (2) & $\mathbf{1 3}$ & Asli (1) & Asli (1) \\
\hline $\mathbf{5}$ & $\begin{array}{l}\text { Asli } \\
(1)\end{array}$ & Palsu (2) & $\mathbf{1 4}$ & Palsu (2) & $\begin{array}{l}\text { Palsu } \\
(2)\end{array}$ \\
\hline $\mathbf{6}$ & $\begin{array}{l}\text { Asli } \\
(1)\end{array}$ & Asli (1) & $\mathbf{1 5}$ & Asli (1) & Asli (1) \\
\hline $\mathbf{7}$ & $\begin{array}{l}\text { Palsu } \\
(2)\end{array}$ & Palsu (2) & $\mathbf{1 6}$ & Asli (1) & Asli (1) \\
\hline $\mathbf{8}$ & $\begin{array}{l}\text { Palsu } \\
(2)\end{array}$ & Palsu (2) & $\mathbf{1 7}$ & Palsu (2) & $\begin{array}{l}\text { Palsu } \\
(2)\end{array}$ \\
\hline
\end{tabular}




\begin{tabular}{|c|c|l|c|c|c|}
\hline No & $\begin{array}{c}\text { Targ } \\
\text { et }\end{array}$ & Klasifikasi & No & Target & $\begin{array}{c}\text { Klasifi } \\
\text { kasi }\end{array}$ \\
\hline $\mathbf{9}$ & $\begin{array}{l}\text { Asli } \\
(1)\end{array}$ & Asli (1) & $\mathbf{1 8}$ & Palsu (2) & $\begin{array}{l}\text { Palsu } \\
(2)\end{array}$ \\
\hline
\end{tabular}

2) Pelatihan dan Pengujian dengan Laju Pembelajaran $\alpha(0)=0,1$ dan Epoch $=5$

Gambar 6 menunjukkan kinerja terbaik jaringan LVQ dalam menentukan kelas dari citra uang kertas adalah pada saat epoch $=2$ tercapai. Nilai MSE jaringan LVQ pada kinerja terbaiknya adalah ketika mencapai nilai 0 . Nilai tersebut menunjukkan bahwa klasifikasi ke kelas yang tidak bersesuaian (missclasification rate) sudah tidak terjadi lagi pada saat jumlah maksimum epoch tercapai. Ketika MSE bernilai 0, hal ini berarti sistem telah mampu untuk menentukan data uang kertas yang dijadikan sebagai masukan termasuk uang kertas asli atau palsu.

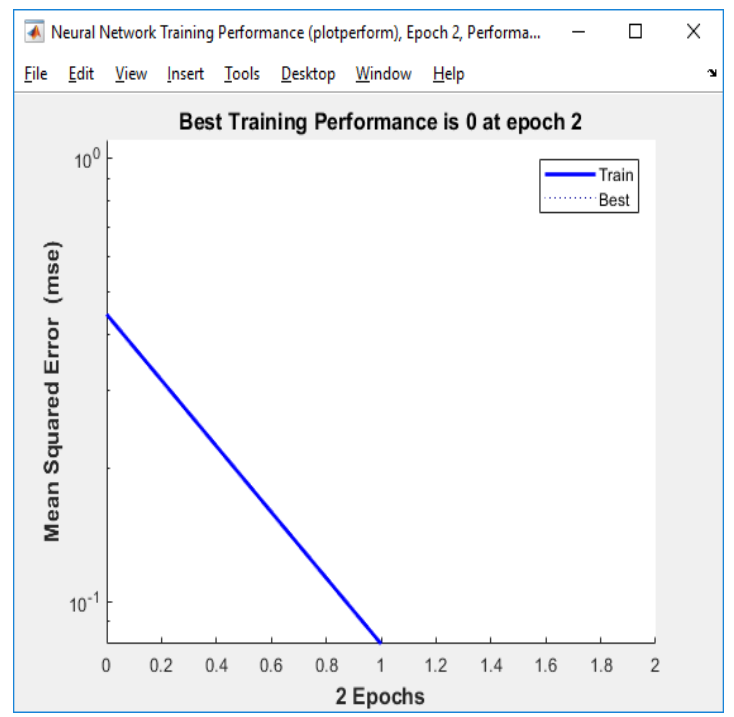

Gambar 6. Grafik Performance Jaringan LVQ pada Laju Pembelajaran $\alpha(0)=0,1$ dan Epoch $=5$

Waktu yang dibutuhkan untuk melakukan pelatihan dan pengujian dengan laju pembelajaran $\alpha(0)=0,1$ dan jumlah maksimum epoch $=5$ adalah 43 detik. Tingkat akurasi jaringan dalam melakukan klasifikasi adalah $100 \%$. Hasil pengujian ditampilkan pada Tabel III.

TABEL IIIII

Hasil Pengujian PADA LAJU PEMBELAJARAN $\alpha(0)=0,1$ DAN EPOCH $=5$

\begin{tabular}{|l|l|l|l|l|l|}
\hline No & Target & Klasifikasi & No & Target & $\begin{array}{c}\text { Klasifik } \\
\text { asi }\end{array}$ \\
\hline $\mathbf{1}$ & Asli (1) & Asli (1) & $\mathbf{1 0}$ & Asli (1) & Asli (1) \\
\hline $\mathbf{2}$ & Palsu (2) & Palsu (2) & $\mathbf{1 1}$ & Asli (1) & Asli (1) \\
\hline $\mathbf{3}$ & Palsu (2) & Palsu (2) & $\mathbf{1 2}$ & Asli (1) & Asli (1) \\
\hline $\mathbf{4}$ & Asli (1) & Asli (1) & $\mathbf{1 3}$ & Palsu (2) & Palsu (2) \\
\hline $\mathbf{5}$ & Asli (1) & Asli (1) & $\mathbf{1 4}$ & Asli (1) & Asli (1) \\
\hline
\end{tabular}

\begin{tabular}{|l|l|l|l|l|l|}
\hline No & Target & Klasifikasi & No & Target & $\begin{array}{c}\text { Klasifik } \\
\text { asi }\end{array}$ \\
\hline $\mathbf{6}$ & Asli (1) & Asli (1) & $\mathbf{1 5}$ & Palsu (2) & Palsu (2) \\
\hline $\mathbf{7}$ & Asli (1) & Asli (1) & $\mathbf{1 6}$ & Palsu (2) & Palsu (2) \\
\hline $\mathbf{8}$ & Palsu (2) & Palsu (2) & $\mathbf{1 7}$ & Palsu (2) & Palsu (2) \\
\hline $\mathbf{9}$ & Asli (1) & Asli (1) & $\mathbf{1 8}$ & Palsu(2) & Palsu (2) \\
\hline
\end{tabular}

3) Pelatihan dan Pengujian dengan Laju Pembelajaran $\alpha(0)=0,01$ dan Epoch $=1$

Gambar 6. menunjukkan kinerja terbaik jaringan LVQ dalam menentukan kelas dari citra uang kertas adalah pada saat jumlah maksimum epoch = 1 tercapai. Nilai MSE jaringan LVQ pada kinerja terbaiknya adalah ketika mencapai nilai 0,17901 . Nilai tersebut menunjukkan bahwa laju klasifikasi ke kelas yang tidak bersesuaian (missclasification rate) paling sedikit terjadi pada saat jaringan mencapai epoch $=1$, yakni sebesar $17,901 \%$.

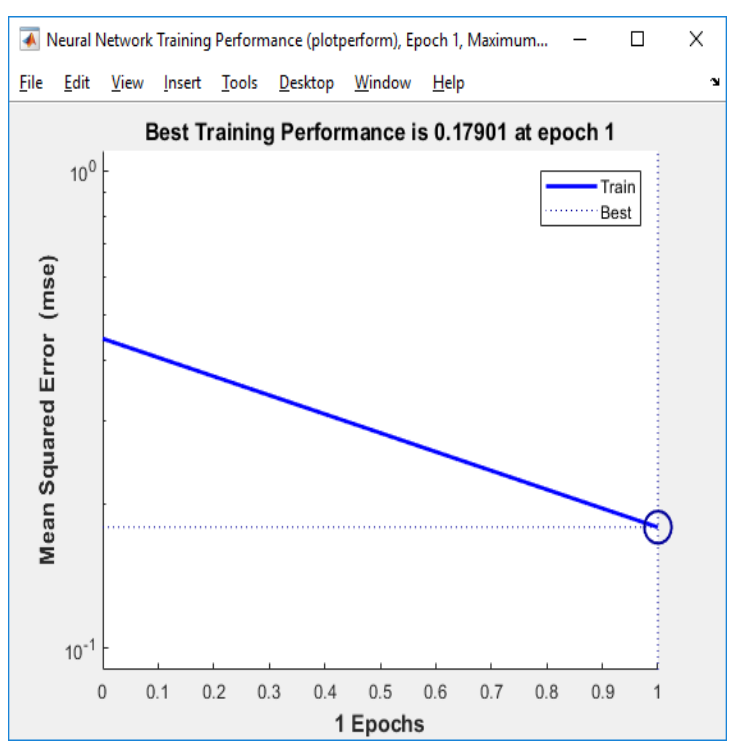

Gambar 6. Grafik Performance Jaringan LVQ pada Laju Pembelajaran $\alpha(0)=0,01$ dan Epoch $=1$

Waktu yang dibutuhkan untuk melakukan pelatihan dan pengujian dengan laju pembelajaran $\alpha(0)=0,01$ dan jumlah maksimum epoch $=1$ adalah 12 detik. Tingkat akurasi jaringan dalam melakukan klasifikasi adalah 83,3\%. Hasil pengujian ditampilkan pada Tabel IV.

TABEL IVV

Hasil PENGUJIAN PADA LAJU PEMBELAJARAN $\alpha(0)=0,01$ DAN EPOCH=1

\begin{tabular}{|l|l|l|l|l|l|}
\hline No & Target & Klasifikasi & No & Target & $\begin{array}{l}\text { Klasifi } \\
\text { kasi }\end{array}$ \\
\hline $\mathbf{1}$ & Asli (1) & Palsu (2) & $\mathbf{1 0}$ & Asli (1) & Asli (1) \\
\hline $\mathbf{2}$ & Palsu (2) & Palsu (2) & $\mathbf{1 1}$ & Asli (1) & Asli (1) \\
\hline $\mathbf{3}$ & Palsu (2) & Palsu (2) & $\mathbf{1 2}$ & Palsu (2) & Asli (1) \\
\hline $\mathbf{4}$ & Asli (1) & Asli (1) & $\mathbf{1 3}$ & Palsu (2) & $\begin{array}{l}\text { Palsu } \\
(2)\end{array}$ \\
\hline
\end{tabular}




\begin{tabular}{|c|l|l|l|l|l|}
\hline No & Target & Klasifikasi & No & Target & $\begin{array}{l}\text { Klasifi } \\
\text { kasi }\end{array}$ \\
\hline $\mathbf{5}$ & Asli (1) & Asli (1) & $\mathbf{1 4}$ & Asli (1) & Asli (1) \\
\hline $\mathbf{6}$ & Asli (1) & Asli (1) & $\mathbf{1 5}$ & Asli (1) & $\begin{array}{l}\text { Palsu } \\
(2)\end{array}$ \\
\hline $\mathbf{7}$ & Palsu (2) & Asli (1) & $\mathbf{1 6}$ & Asli (1) & $\begin{array}{l}\text { Palsu } \\
(2)\end{array}$ \\
\hline $\mathbf{8}$ & Palsu (2) & Palsu (2) & $\mathbf{1 7}$ & Palsu (2) & Asli (1) \\
\hline $\mathbf{9}$ & Asli (1) & Asli (1) & $\mathbf{1 8}$ & Palsu (2) & $\begin{array}{l}\text { Palsu } \\
(2)\end{array}$ \\
\hline
\end{tabular}

4) Pelatihan dan Pengujian dengan Laju Pembelajaran $\alpha(0)=0,01$ dan Epoch $=5$

Gambar 7 menunjukkan kinerja terbaik jaringan LVQ dalam menentukan kelas dari citra uang kertas adalah pada saat jumlah maksimum epoch = 5 tercapai. Nilai MSE jaringan LVQ pada kinerja terbaiknya adalah ketika mencapai nilai 0,055556 . Nilai tersebut menunjukkan bahwa laju klasifikasi ke kelas yang tidak bersesuaian (missclasification rate) paling sedikit terjadi pada saat jaringan mencapai epoch $=5$, yakni sebesar 5,5556\%

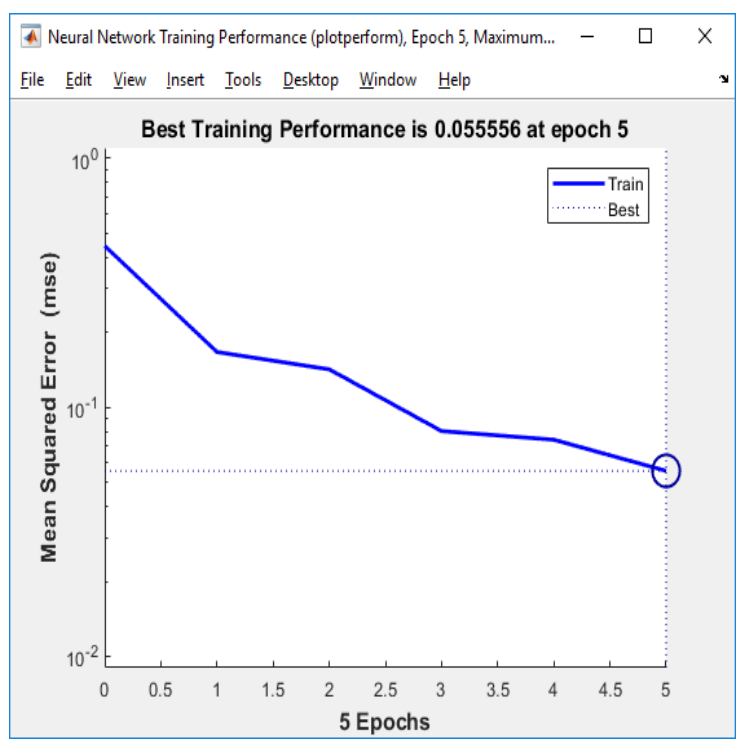

Gambar 7. Grafik Performance Jaringan LVQ pada Laju Pembelajaran $\alpha(0)=0,01$ dan Epoch $=5$

Waktu yang dibutuhkan untuk melakukan pelatihan dan pengujian dengan laju pembelajaran $\alpha(0)=$ 0,01 dan jumlah maksimum epoch $=5$ adalah 43 detik. Tingkat akurasi jaringan dalam melakukan klasifikasi adalah 94,4\%. Hasil pengujian ditampilkan pada Tabel V.

TABEL V

Hasil Pengujian PADA Laju PEMBELAJARAN $\alpha(0)=0,01$ DAN EPOC $=5$

\begin{tabular}{|c|c|c|c|c|c|}
\hline No & Target & Klasifikasi & No & Target & $\begin{array}{c}\text { Klasifi } \\
\text { kasi }\end{array}$ \\
\hline
\end{tabular}

\begin{tabular}{|c|l|l|c|l|l|}
\hline No & Target & Klasifikasi & No & Target & $\begin{array}{l}\text { Klasifi } \\
\text { kasi }\end{array}$ \\
\hline $\mathbf{1}$ & Palsu (2) & Palsu (2) & $\mathbf{1 0}$ & Asli (1) & $\begin{array}{l}\text { Asli } \\
(1)\end{array}$ \\
\hline $\mathbf{2}$ & Asli (1) & Asli (1) & $\mathbf{1 1}$ & Palsu (2) & $\begin{array}{l}\text { Palsu } \\
(2)\end{array}$ \\
\hline $\mathbf{3}$ & Asli (1) & Asli (1) & $\mathbf{1 2}$ & Palsu (2) & $\begin{array}{l}\text { Palsu } \\
(2)\end{array}$ \\
\hline $\mathbf{4}$ & Asli (1) & Asli (1) & $\mathbf{1 3}$ & Palsu (2) & $\begin{array}{l}\text { Palsu } \\
(2)\end{array}$ \\
\hline $\mathbf{5}$ & Palsu (2) & Palsu (2) & $\mathbf{1 4}$ & Asli (1) & $\begin{array}{l}\text { Palsu } \\
(2)\end{array}$ \\
\hline $\mathbf{6}$ & Palsu (2) & Palsu (2) & $\mathbf{1 5}$ & Asli (1) & $\begin{array}{l}\text { Asli } \\
(1)\end{array}$ \\
\hline $\mathbf{7}$ & Palsu (2) & Palsu (2) & $\mathbf{1 6}$ & Palsu (2) & $\begin{array}{l}\text { Palsu } \\
(2)\end{array}$ \\
\hline $\mathbf{8}$ & Asli (1) & Asli (1) & $\mathbf{1 7}$ & Asli (1) & $\begin{array}{l}\text { Asli } \\
(1)\end{array}$ \\
\hline $\mathbf{9}$ & Asli (1) & Asli (1) & $\mathbf{1 8}$ & Asli (1) & $\begin{array}{l}\text { Asli } \\
(1)\end{array}$ \\
\hline
\end{tabular}

Berdasarkan hasil pengujian jaringan LVQ dengan menggunakan laju pembelajaran $\alpha(0)=0,1$ dan $\alpha(0)=0,01$ yang masing-masing diujikan dengan maksimum epoch $=1$ dan maksimum epoch $=5$ diketahui bahwa klasifikasi ke kelas yang tidak bersesuaian, baik false positive maupun false negative, jumlahnya akan menurun ketika jumlah maksimum epoch ditingkatkan.

\section{F. Implementasi Jaringan Backpropagation}

Implementasi jaringan Backpropagation dilakukan dengan menggunakan MATLAB seperti yang ditampilkan pada Gambar 8. Fungsi MATLAB yang dijalankan adalah newff. Algoritma pelatihan yang digunakan pada jaringan Backpropagation adalah Gradient Descent with Momentum \& Adaptive Learning Rate (LR). Gradient Descent with Momentum \& Adaptive Learning Rate (LR) dipilih karena penambahan parameter momentum dalam proses update bobot seringkali mampu mempercepat proses pelatihan. Penambahan momentum dimaksudkan untuk menghindari perubahan bobot yang mencolok akibat adanya data yang outlier. Namun, apabila data terakhir memiliki pola yang berbeda dengan yang lainnya, perubahan dilakukan secara lambat. Selain penambahan momentum, dalam pelatihan ini juga menerapkan adaptive learning rate yang merupakan suatu konstanta yang dapat digunakan dalam seluruh epoch. Perubahan dapat dilakukan dengan memberikan learning rate yang berbeda-beda untuk setiap epoch-nya. Sama halnya seperti di jaringan LVQ, hasil konversi nilai RGB citra uang kertas ke dalam ruang warna HSV dijadikan sebagai vektor masukan pada jaringan Backpropagation yang dibentuk. Jumlah elemen pada vektor masukan adalah 40.320. Jaringan Backpropagation yang dibentuk terdiri dari lapisan masukan (input) dengan jumlah 40.320 yang sesuai dengan jumlah elemen pada vektor masukan, 2 lapisan tersembunyi (hidden layer) dengan masing-masing memiliki 2 neuron, dan lapisan keluaran (output layer) dengan jumlah 
2 neuron. Keluaran dari jaringan LVQ direpresentasikan ke dalam dua kelas, yakni kelas 1 untuk kategori asli dan kelas 2 untuk kategori palsu. Jumlah maksimum epoch yang digunakan adalah 1000

Jaringan Backpropagation yang dibentuk dilatih berdasarkan laju pembelajaran dan jumlah maksimum epoch yang digunakan dalam menentukan kelas yang sesuai untuk data latih. Data latih yang digunakan terdiri dari 10 uang kertas asli dan 8 uang kertas palsu. Setiap data, baik uang asli maupun palsu dilakukan pengambilan citra sebanyak 9 kali, sehingga komposisi data latih yang digunakan terdiri dari 90 citra uang asli dan 72 citra uang palsu. Jaringan Backpropagation yang telah dilatih selanjutnya diuji dalam melakukan klasifikasi untuk menentukan citra data uji yang digunakan adalah uang asli atau uang palsu. Komposisi data uji yang digunakan terdiri dari 10 citra uang asli dan 8 citra uang palsu.

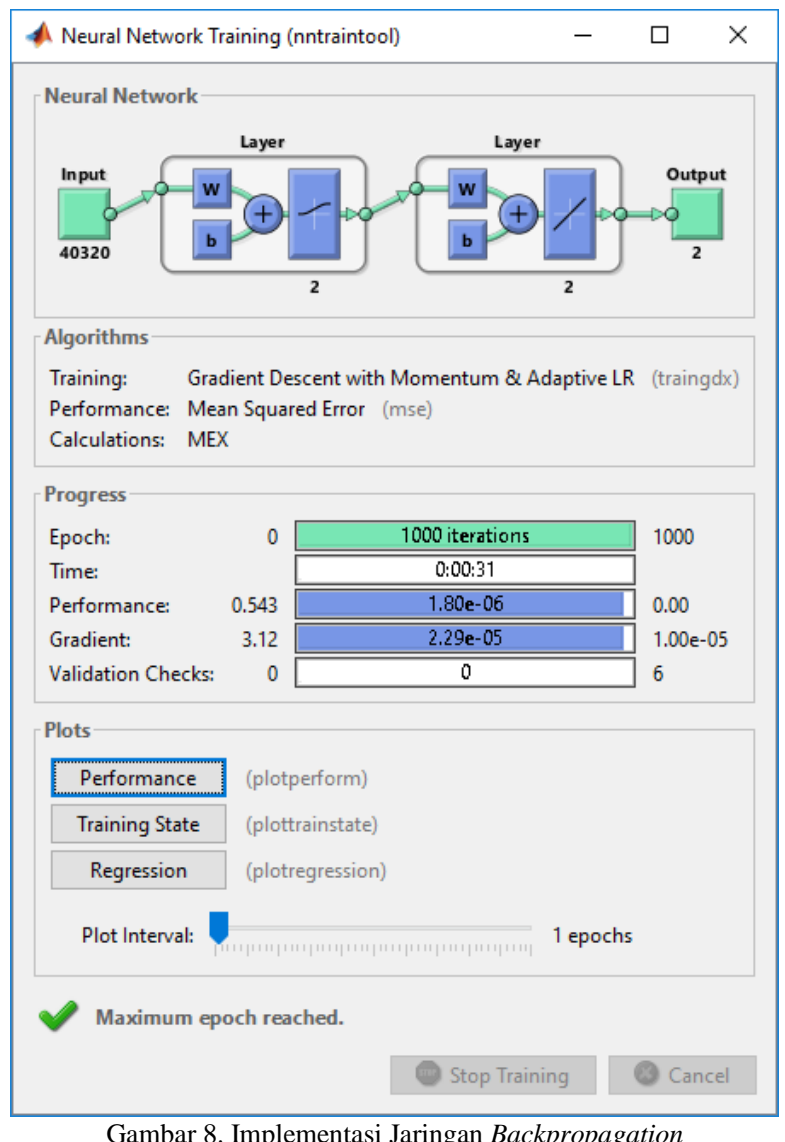

1) Pelatihan dan Pengujian dengan Laju Pembelajaran $\alpha(0)=0,1$

Gambar 9 menunjukkan kinerja terbaik jaringan Backpropagation dalam menentukan kelas dari citra uang kertas adalah pada saat jumlah epoch $=$ 89 tercapai. Nilai MSE jaringan Backpropagation pada kinerja terbaiknya adalah ketika mencapai nilai 0,24691 . Nilai tersebut menunjukkan bahwa laju klasifikasi ke kelas yang tidak bersesuaian (missclasification rate) paling sedikit terjadi pada saat jaringan mencapai epoch $=89$, yakni sebesar $24,691 \%$.

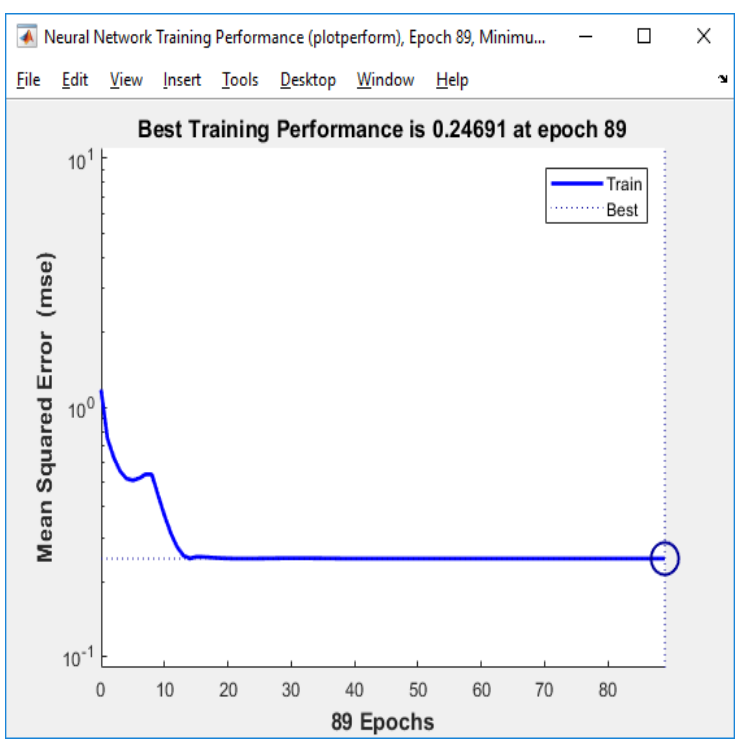

Gambar 9. Grafik Performance Jaringan Backpropagation pada Laju Pembelajaran

Waktu yang dibutuhkan untuk melakukan pelatihan dan pengujian dengan laju pembelajaran $\alpha(0)=1$ adalah 4 detik. Tingkat akurasi jaringan dalam melakukan klasifikasi adalah 55,6\%. Hasil pengujian ditampilkan pada Tabel VI.

TABEL VI

Hasil Pengujian Pada LaJu Pembelajaran

\begin{tabular}{|c|c|l|c|l|l|}
\hline No & Target & $\begin{array}{l}\text { Klasifi } \\
\text { kasi }\end{array}$ & No & Target & $\begin{array}{l}\text { Klasif } \\
\text { ikasi }\end{array}$ \\
\hline $\mathbf{1}$ & Palsu (2) & $\begin{array}{l}\text { Asli } \\
(1)\end{array}$ & $\mathbf{1 0}$ & Asli (1) & $\begin{array}{l}\text { Asli } \\
(1)\end{array}$ \\
\hline $\mathbf{2}$ & Asli (1) & $\begin{array}{l}\text { Asli } \\
(1)\end{array}$ & $\mathbf{1 1}$ & Asli (1) & $\begin{array}{l}\text { Asli } \\
(1)\end{array}$ \\
\hline $\mathbf{3}$ & Palsu (2) & $\begin{array}{l}\text { Asli } \\
(1)\end{array}$ & $\mathbf{1 2}$ & Palsu (2) & $\begin{array}{l}\text { Asli } \\
(1)\end{array}$ \\
\hline $\mathbf{4}$ & Palsu (2) & $\begin{array}{l}\text { Asli } \\
(1)\end{array}$ & $\mathbf{1 3}$ & Palsu (2) & $\begin{array}{l}\text { Asli } \\
(1)\end{array}$ \\
\hline $\mathbf{5}$ & Asli (1) & $\begin{array}{l}\text { Asli } \\
(1)\end{array}$ & $\mathbf{1 4}$ & Asli (1) & $\begin{array}{l}\text { Asli } \\
(1)\end{array}$ \\
\hline $\mathbf{6}$ & Asli (1) & $\begin{array}{l}\text { Asli } \\
(1)\end{array}$ & $\mathbf{1 5}$ & Asli (1) & $\begin{array}{l}\text { Asli } \\
(1)\end{array}$ \\
\hline $\mathbf{7}$ & Asli (1) & $\begin{array}{l}\text { Asli } \\
(1)\end{array}$ & $\mathbf{1 6}$ & Asli (1) & $\begin{array}{l}\text { Asli } \\
(1)\end{array}$ \\
\hline $\mathbf{8}$ & Asli (1) & $\begin{array}{l}\text { Asli } \\
(1)\end{array}$ & $\mathbf{1 7}$ & Palsu (2) & $\begin{array}{l}\text { Asli } \\
(1)\end{array}$ \\
\hline $\mathbf{9}$ & Palsu (2) & $\begin{array}{l}\text { Asli } \\
(1)\end{array}$ & $\mathbf{1 8}$ & Palsu (2) & $\begin{array}{l}\text { Asli } \\
(1)\end{array}$ \\
\hline
\end{tabular}

2) Pelatihan dan Pengujian dengan Laju Pembelajaran $\alpha(0)=0,01$ 
Gambar 10 menunjukkan kinerja terbaik jaringan Backpropagation dalam menentukan kelas dari citra uang kertas adalah pada saat jumlah epoch = 155 tercapai. Nilai MSE jaringan Backpropagation pada kinerja terbaiknya adalah ketika mencapai nilai 0,24691. Nilai tersebut menunjukkan bahwa laju klasifikasi ke kelas yang tidak bersesuaian (missclasification rate) paling sedikit terjadi pada saat jaringan mencapai epoch $=155$, yakni sebesar $24,691 \%$. Terlihat bahwa ketika laju pembelajaran $\alpha(0)=0,1$ dan $\alpha(0)=0,01$ tidak ada perubahan nilai MSE yang terjadi.

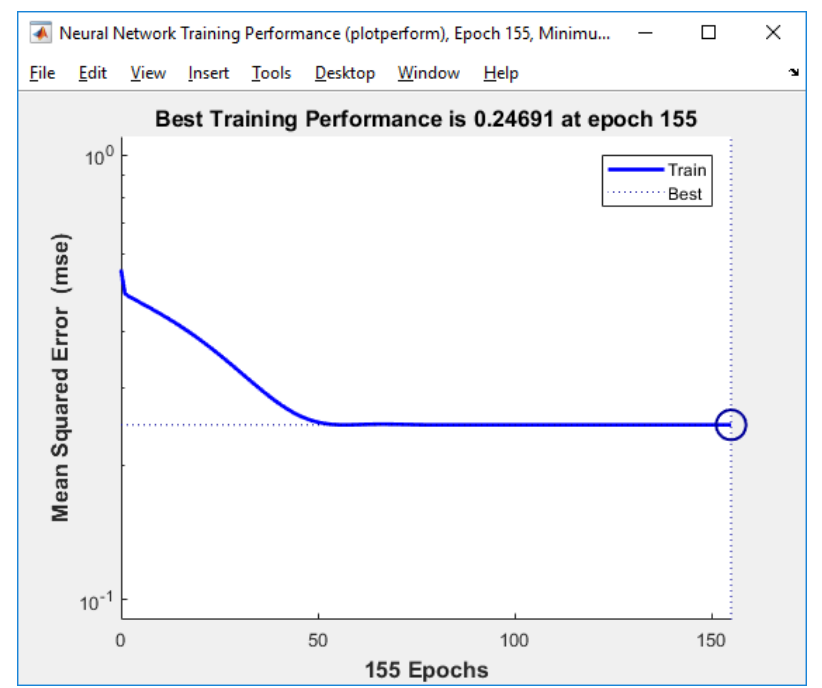

Gambar 10. Grafik Performance Jaringan Backpropagation pada Laju Pembelajaran $\alpha(0)=0,01$

Waktu yang dibutuhkan untuk melakukan pelatihan dan pengujian dengan laju pembelajaran $\alpha(0)=$ 0,01 adalah 6 detik. Tingkat akurasi jaringan dalam melakukan klasifikasi adalah 55,6\%. Terlihat dari sisi tingkat akurasi juga memiliki kesamaan dengan laju pembelajaran $\alpha(0)=0,1$. Hasil pengujian ditampilkan pada Tabel VII.

TABEL VII

Hasil Pengujian Pada Laju Pembelajaran A $(0)=0,01$

\begin{tabular}{|c|c|l|c|l|l|}
\hline No & Target & $\begin{array}{l}\text { Klasifi } \\
\text { kasi }\end{array}$ & No & Target & $\begin{array}{l}\text { Klasifi } \\
\text { kasi }\end{array}$ \\
\hline $\mathbf{1}$ & Palsu (2) & $\begin{array}{l}\text { Asli } \\
(1)\end{array}$ & $\mathbf{1 0}$ & Asli (1) & $\begin{array}{l}\text { Asli } \\
(1)\end{array}$ \\
\hline $\mathbf{2}$ & Palsu (2) & $\begin{array}{l}\text { Asli } \\
(1)\end{array}$ & $\mathbf{1 1}$ & Asli (1) & $\begin{array}{l}\text { Asli } \\
(1)\end{array}$ \\
\hline $\mathbf{3}$ & Palsu (2) & $\begin{array}{l}\text { Asli } \\
(1)\end{array}$ & $\mathbf{1 2}$ & Asli (1) & $\begin{array}{l}\text { Asli } \\
(1)\end{array}$ \\
\hline $\mathbf{4}$ & Palsu (2) & $\begin{array}{l}\text { Asli } \\
(1)\end{array}$ & $\mathbf{1 3}$ & Asli (1) & $\begin{array}{l}\text { Asli } \\
(1)\end{array}$ \\
\hline $\mathbf{5}$ & Asli (1) & $\begin{array}{l}\text { Asli } \\
(1)\end{array}$ & $\mathbf{1 4}$ & Palsu (2) & $\begin{array}{l}\text { Asli } \\
(1)\end{array}$ \\
\hline $\mathbf{6}$ & Asli (1) & $\begin{array}{l}\text { Asli } \\
(1)\end{array}$ & $\mathbf{1 5}$ & Asli (1) & $\begin{array}{l}\text { Asli } \\
(1)\end{array}$ \\
\hline
\end{tabular}

\begin{tabular}{|c|c|l|c|l|l|}
\hline No & Target & $\begin{array}{l}\text { Klasifi } \\
\text { kasi }\end{array}$ & No & Target & $\begin{array}{l}\text { Klasifi } \\
\text { kasi }\end{array}$ \\
\hline $\mathbf{7}$ & Palsu (2) & $\begin{array}{l}\text { Asli } \\
(1)\end{array}$ & $\mathbf{1 6}$ & Asli (1) & $\begin{array}{l}\text { Asli } \\
(1)\end{array}$ \\
\hline $\mathbf{8}$ & Palsu (2) & $\begin{array}{l}\text { Asli } \\
(1)\end{array}$ & $\mathbf{1 7}$ & Asli (1) & $\begin{array}{l}\text { Asli } \\
(1)\end{array}$ \\
\hline $\mathbf{9}$ & Asli (1) & $\begin{array}{l}\text { Asli } \\
(1)\end{array}$ & $\mathbf{1 8}$ & Palsu (2) & $\begin{array}{l}\text { Asli } \\
(1)\end{array}$ \\
\hline
\end{tabular}

3) Pelatihan dan Pengujian dengan Laju Pembelajaran $\alpha(0)=0,001$

Gambar 11 menunjukkan kinerja terbaik jaringan Backpropagation dalam menentukan kelas dari citra uang kertas adalah pada saat jumlah epoch = 999 tercapai. Nilai MSE jaringan Backpropagation pada kinerja terbaiknya adalah ketika mencapai nilai 0,00042753. Nilai tersebut menunjukkan bahwa laju klasifikasi ke kelas yang tidak bersesuaian (missclasification rate) paling sedikit terjadi pada saat jaringan mencapai epoch $=999$, yakni sebesar $0,042753 \%$.

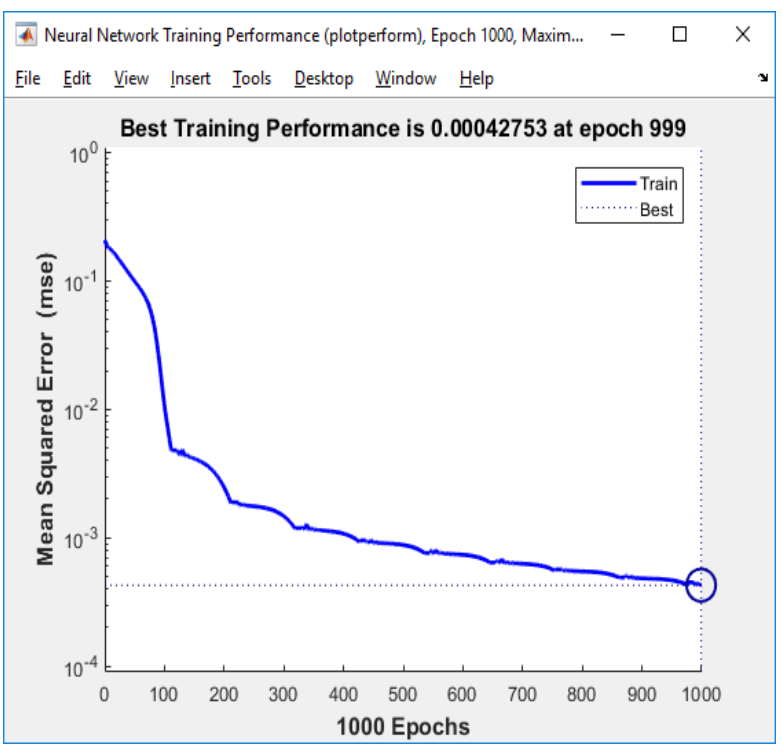

Gambar 11. Grafik Performance Jaringan Backpropagation pada Laju Pembelajaran $\alpha(0)=0,001$

Waktu yang dibutuhkan untuk melakukan pelatihan dan pengujian dengan laju pembelajaran $\alpha(0)=$ 0,001 adalah 27 detik. Tingkat akurasi jaringan dalam melakukan klasifikasi adalah 100\%. Hasil pengujian ditampilkan pada Tabel VIII.

TABEL VIII

Hasil Pengujian Pada Laju Pembelajaran a $(0)=0,001$

\begin{tabular}{|c|l|l|c|l|l|}
\hline No & Target & Klasifikasi & No & Target & Klasifikasi \\
\hline $\mathbf{1}$ & Asli (1) & Asli (1) & $\mathbf{1 0}$ & $\begin{array}{l}\text { Palsu } \\
(2)\end{array}$ & Palsu (2) \\
\hline $\mathbf{2}$ & $\begin{array}{l}\text { Palsu } \\
(2)\end{array}$ & Palsu (2) & $\mathbf{1 1}$ & $\begin{array}{l}\text { Palsu } \\
(2)\end{array}$ & Palsu (2) \\
\hline
\end{tabular}




\begin{tabular}{|c|l|l|c|l|l|}
\hline $\mathbf{3}$ & Asli (1) & Asli (1) & $\mathbf{1 2}$ & $\begin{array}{l}\text { Palsu } \\
(2)\end{array}$ & Palsu (2) \\
\hline $\mathbf{4}$ & Asli (1) & Asli (1) & $\mathbf{1 3}$ & $\begin{array}{l}\text { Palsu } \\
(2)\end{array}$ & Palsu (2) \\
\hline $\mathbf{5}$ & Asli (1) & Asli (1) & $\mathbf{1 4}$ & $\begin{array}{l}\text { Palsu } \\
(2)\end{array}$ & Palsu (2) \\
\hline $\mathbf{6}$ & Asli (1) & Asli (1) & $\mathbf{1 5}$ & $\begin{array}{l}\text { Asli } \\
(1)\end{array}$ & Asli (1) \\
\hline $\mathbf{7}$ & $\begin{array}{l}\text { Palsu } \\
(2)\end{array}$ & Palsu (2) & $\mathbf{1 6}$ & $\begin{array}{l}\text { Palsu } \\
(2)\end{array}$ & Palsu (2) \\
\hline $\mathbf{8}$ & Asli (1) & Asli (1) & $\mathbf{1 7}$ & $\begin{array}{l}\text { Asli } \\
(1)\end{array}$ & Asli (1) \\
\hline $\mathbf{9}$ & Asli (1) & Asli (1) & $\mathbf{1 8}$ & $\begin{array}{l}\text { Asli } \\
(1)\end{array}$ & Asli (1) \\
\hline
\end{tabular}

4) Pelatihan dan Pengujian dengan Laju Pembelajaran $\alpha(0)=0,0001$

Gambar 12 menunjukkan kinerja terbaik jaringan Backpropagation dalam menentukan kelas dari citra uang kertas adalah pada saat jumlah epoch $=$ 990 tercapai. Nilai MSE jaringan Backpropagation pada kinerja terbaiknya adalah ketika mencapai nilai 0,00088765 . Nilai tersebut menunjukkan bahwa laju klasifikasi ke kelas yang tidak bersesuaian (missclasification rate) paling sedikit terjadi pada saat jaringan mencapai epoch $=990$, yakni sebesar $0,088765 \%$.

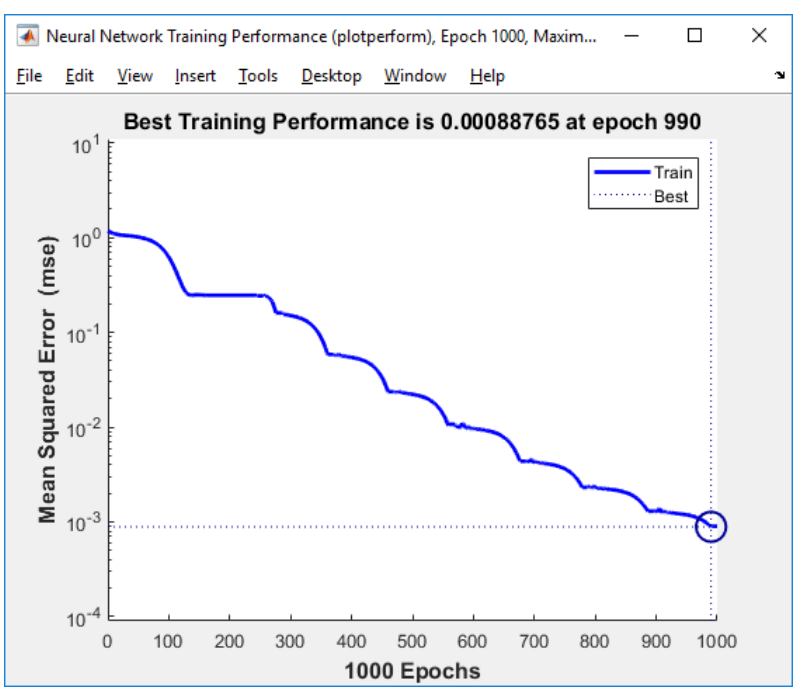

Gambar 12. Grafik Performance Jaringan Backpropagation pada Laju Pembelajaran $\alpha(0)=0,0001$

Waktu yang dibutuhkan untuk melakukan pelatihan dan pengujian dengan laju pembelajaran $\alpha(0)=$ 0,0001 adalah 26 detik. Tingkat akurasi jaringan dalam melakukan klasifikasi adalah $100 \%$. Hasil pengujian ditampilkan pada Tabel IX.

TABEL IX

Hasil Pengujian Pada Laju Pembelajaran A $(0)=0,0001$

\begin{tabular}{|c|c|l|c|l|l|}
\hline No & Target & $\begin{array}{l}\text { Klasifi } \\
\text { kasi }\end{array}$ & No & Target & $\begin{array}{l}\text { Klasifi } \\
\text { kasi }\end{array}$ \\
\hline $\mathbf{1}$ & Palsu (2) & $\begin{array}{l}\text { Palsu } \\
(2)\end{array}$ & $\mathbf{1 0}$ & Asli (1) & Asli (1) \\
\hline $\mathbf{2}$ & Palsu (2) & $\begin{array}{l}\text { Palsu } \\
(2)\end{array}$ & $\mathbf{1 1}$ & Asli (1) & Asli (1) \\
\hline $\mathbf{3}$ & Palsu (2) & $\begin{array}{l}\text { Palsu } \\
(2)\end{array}$ & $\mathbf{1 2}$ & Palsu (2) & $\begin{array}{l}\text { Palsu } \\
(2)\end{array}$ \\
\hline $\mathbf{4}$ & Asli (1) & Asli (1) & $\mathbf{1 3}$ & Palsu (2) & $\begin{array}{l}\text { Palsu } \\
(2)\end{array}$ \\
\hline $\mathbf{5}$ & Asli (1) & Asli (1) & $\mathbf{1 4}$ & Palsu (2) & $\begin{array}{l}\text { Palsu } \\
(2)\end{array}$ \\
\hline $\mathbf{6}$ & Asli (1) & Asli (1) & $\mathbf{1 5}$ & Palsu (2) & $\begin{array}{l}\text { Palsu } \\
(2)\end{array}$ \\
\hline $\mathbf{7}$ & Asli (1) & Asli (1) & $\mathbf{1 6}$ & Asli (1) & Asli (1) \\
\hline $\mathbf{8}$ & Asli (1) & Asli (1) & $\mathbf{1 7}$ & Asli (1) & Asli (1) \\
\hline $\mathbf{9}$ & Asli (1) & Asli (1) & $\mathbf{1 8}$ & Palsu (2) & $\begin{array}{l}\text { Palsu } \\
(2)\end{array}$ \\
\hline
\end{tabular}

Berdasarkan hasil pengujian jaringan Backpropagation dengan menggunakan laju pembelajaran $\alpha(0)=0,1 ; \alpha(0)=$ 0,$01 ; \alpha(0)=0,001 ;$ dan $\alpha(0)=0,0001$ diketahui bahwa klasifikasi ke kelas yang tidak bersesuaian, baik false positive maupun false negative, jumlahnya akan menurun seiring menurunnya laju pembelajaran.

\section{KESIMPULAN}

Dari hasil penelitian yang sudah dilakukan dapat diambil kesimpulan sebagai berikut :

1) Sistem diimplementasikan dengan melalui tahap akuisisi citra, pra-pemrosesan citra, ekstraksi fitur, dan klasifikasi citra. Akuisisi citra dan prapemrosesan citra merupakan tahap yang dilakukan secara terpisah dari sistem. Ekstraksi fitur diimplementasikan dengan menggunakan fungsi MATLAB rgb2hsv. Klasifikasi citra dengan jaringan LVQ diimplementasikan dengan fungsi MATLAB lvqnet, sedangkan untuk jaringan Backpropagation diimplementasikan dengan fungsi MATLAB newf $f$

2) Berdasarkan hasil pengujian sistem yang diperoleh dapat disimpulkan bahwa dengan menggunakan metode jaringan syaraf tiruan LVQ maupun Backpropagation, sistem mampu mengklasifikasi citra uang kertas dengan tingkat akurasi $100 \%$. Namun, jika dilihat dari nilai MSE, maka jaringan LVQ memiliki kinerja yang lebih baik karena nilai MSE yang dicapai adalah 0 .

3) Berdasarkan hasil pengujian sistem dari sisi waktu, jaringan Backpropagation memiliki waktu pemrosesan yang jauh lebih singkat dibandingkan dengan jaringan LVQ. Hal tersebut ditunjukkan oleh jumlah maksimum epoch yang digunakan. Jaringan LVQ hanya menggunakan jumlah maksimum epoch 5, tetapi waktu yang dibutuhkan mencapai 43 detik, sedangkan jaringan Backpropagation dengan jumlah maksimum epoch 
1000, waktu yang dibutuhkan hanya mencapai 27 detik.

\section{UCAPAN TERIMA KASIH}

Ucapan terima kasih peneliti tujukan kepada institusi STMIK STIKOM INDONESIA yang telah membantu dalam pendaan penelitian ini

\section{DAFTAR PUSTAKA}

[1] Wicaksono, D. D. G. (2007). Perangkat Lunak Identifikasi Nilai Nominal dan Keaslian Uang Kertas Rupiah Menggunakan Jaringan Syaraf Tiruan Backpropagation. Skripsi. Departemen Teknik Elektro Fakultas Teknik Universitas Indonesia.

[2] Jalil, A. (2016). SISTEM KONTROL DETEKSI NOMINAL UANG KERTAS RUPIAH MENGGUNAKAN IMAGE PROCESSING RASPBERRY PI. JURNAL IT : Media Informasi STMIK Handayani Makassar, 15(0).

[3] Pendeteksi Nominal dan Keaslian Uang Kertas Rupiah untuk Penyandang Tuna Netra Berbasis Arduino Ikhsan, S., \& Permata Sari, P. S. (n.d.). Ikhsan Sistem Pendeteksi Nominal dan Keaslian.
[4] Republik Indonesia. 2011._Undang-Undang Nomor 7 Tahun 2011 tentang Mata Uang. Sekretariat Negara. Jakarta.

[5] Republik Indonesia. 1999. Undang-Undang Nomor 23 Tahun 1999 tentang Bank Indonesia. Sekretariat Negara. Jakarta.

[6] Andono, P. N., Sutojo, T., \& Muljono. (2018). Pengolahan Citra Digital. Yogyakarta: Penerbit Andi.

[7] Putra, D. (2010). Pengolahan Citra Digital. Yogyakarta: Penerbit Andi.

[8] P. D. Pawar \& S. B. Kale, "Recognition of Indian Currency Note Based on HSV Parameters", International Journal of Science and Research, vol. 3, pp. 132-137, June. 2014.

[9] Jasril, M. S. Cahyana, L. Handayani, \& E. Budianita (2015). "Implementasi Learning Vektor Quantization (LVQ) dalam Mengidentifikasi Citra Daging Babi dan Daging Sapi", Seminar Nasional Teknologi Informasi, Komunikasi dan Industri (SNTIKI) 7 , 2015, p. 176-184

[10] S. O. Haykin. Neural Networks and Learning Machines, 3rd ed. Ontario: Pearson, 2009

[11] Fausett, L. (1994). Fundamentals of Neural Networks: Architectures, Algorithms, and Applications. New Jersey: Prentice-Hall 